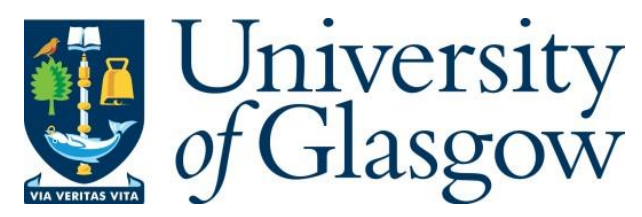

Moreda Rodriguez, E. (2020) Why do orchestral and band musicians in exile matter? A case study from Spain. Music and Letters, 101(1), pp. 71-88.

There may be differences between this version and the published version. You are advised to consult the publisher's version if you wish to cite from it.

http://eprints.gla.ac.uk/180004/

Deposited on: 15 February 2019

Enlighten - Research publications by members of the University of Glasgow http://eprints.gla.ac.uk 


\section{Why do orchestral and band musicians in exile matter? A case study from Spain}

Bibliography on music and exile under the Franco regime in Spain has grown steadily for the past three decades, ${ }^{1}$ but little attention has been paid thus far to exiled musicians who were active primarily as performers in orchestras, wind bands and other ensembles. By focusing on a group of such musicians (grouped in the Banda Madrid or Agrupación Musical Madrid), this article aims to outline questions concerning the relationship between music in exile, modernity and politics and, in doing so, to invite reconsideration of the historiographical foundations of the study of music in exile, primarily in Spain, but also elsewhere.

Orchestral and band musicians being practically absent from research on music and exile in Spain, so reconstructing the trajectory of the Banda Madrid and of its members has obvious intrinsic interest in terms of uncovering facts and shedding light on forgotten stories. ${ }^{2}$ But, beyond individual personalities and trajectories, what makes the study the Banda Madrid worthwhile is - as I hope to

\footnotetext{
${ }^{1}$ Although the late 1970s and early 1980s saw the first studies of individual exiled composers, such as Antonio Iglesias, Rodolfo Halffter. Su obra para piano (Madrid, 1979) and María Luisa Mallo del Campo, Torner. Más allá del folklore (Oviedo, 1980), it was Emilio Casares Rodicio who in 1986 and 1987 published two texts that would shape the study of exile considerably: Emilio Casares Rodicio, 'La música española hasta 1939, o la restauración musical', in Emilio Casares Rodicio, Ismael Fernández de la Cuesta and José López-Calo (eds.), España en la música de Occidente (Madrid, 1987), 261-322 (which will be discussed in more detail subsequently) and Emilio Casares Rodicio (ed.), La música en la Generación del 27. Homenaje a Lorca 19151939 (Madrid: Ministerio de Cultura/INAEM, 1986). Subsequent studies have focused mostly on individual exiled composers and they vary in their critical engagement with the category of exile. Comparative perspectives, as well as a broader reflection on the historiographical problems posed by exile, are still scarce, but the following studies merit a mention: Susana Asensio, 'Eduardo Martínez Torner y la Junta para Ampliación de Estudios en España', Arbor, 187 (2011), 857-874, Consuelo Carredano (ed.), Adolfo Salazar. Epistolario. 1912-1958 (Madrid: 2008); Christiane Heine, 'Salvador Bacarisse (1898-1963) en el centenario de su nacimiento', Cuadernos de música iberoamericana , 5 (1998), 43-75; Samuel Llano, 'Exile, Resistance and Heteroglossia in Roberto Gerhard's "Flamenco", in Helena Buffery (ed.), Stages of Exile: Spanish Republican Exile Theatre and Performance (Oxford and New York, 2011), 107-124); Samuel Llano, 'Roberto Gerhard, Shakespeare and the Memorial Theatre', in Monty Adkins and Michael Russ (eds.), The Roberto Gerhard Companion (Farnham, 2013), 107-130; María Victoria García Martínez, El regreso de Óscar Esplá a Alicante en 1950 (Alicante, 2010), Eva Moreda Rodríguez, 'Francoism and the republican Exiles: the case of the composer Julián Bautista (1901-61)', Twentieth-Century Music, 8 (2011), 153-173; Eva Moreda Rodríguez, 'Transatlantic networks in the correspondence of two exiled Spanish musicians, Julián Bautista and Adolfo Salazar', Journal of the Royal Musical Association, 140 (2015), 93-119; Eva Moreda Rodríguez, Music and exile in Francoist Spain (Farnham, 2013); Jorge de Persia, Julián Bautista (Madrid, 2005), Leticia Sánchez de Andrés, Roberto Gerhard's Ballets: Music, Ideology and Passion in Monty Adkins and M. Russ (eds.), The Roberto Gerhard Companion (Farnham, 2013), 79-105; Julian White, 'National Traditions in the Music of Roberto Gerhard', Tempo, 184 (1993), 2-13; Julian White, 'Promoting and Diffusing Catalan Musical Heritage: Roberto Gerhard and Catalan Folk Music', in Monty Adkins and Michael Russ (eds.), The Roberto Gerhard Companion (Farnham, 2013), 49-77.

${ }^{2}$ While I will make reference to the employment circumstances of a few selected members of the Banda Madrid throughout this article, table 1 provides a more comprehensive overview of their careers pre- and post-exile
} 
demonstrate in the course of this article - its role as a key agent in the early development of the new Spanish identities that surfaced in exile. The Banda can be regarded to have undertaken this role as early as $9^{\text {th }}$ February 1939, when Franco's army seized north Catalonia, driving the Quinto Cuerpo del Ejército (the fifth unit of the Republican army) across the French border. Members of the Quinto Cuerpo were distributed among various internment camps, with its wind band, including the conductor, Rafael Oropesa Clausín, going to Le Barcarès. There is no evidence as to whether the Banda Madrid performed there, or whether it did so under that name. Nevertheless, with various bouts of cultural activity taking shape in the various camps at this stage - including magazines, newspapers and choirs ${ }^{3}$, as well as self-organized cultural commissions $-{ }^{4}$ it is plausible that the Banda or some of its musicians might have performed in Le Barcarès too, if only informally. One of the reasons that makes the hypothesis plausible is that cultural activity in the internment camps was not simply as a symbol of nostalgia or an attempt by the exiles at keeping themselves occupied: instead, it constituted the first steps in the development of what would come to Spanish exiled culture and identity, of which the Banda Madrid became a key part on board the Sinaia and then in Mexico.

On $25^{\text {th }}$ May 1939, all members of the Banda Madrid boarded the Sinaia in Sète, destination Veracruz. This was the first of several ships chartered jointly by the Mexican government and the Servicio de Evacuación de Refugiados Españoles (SERE) in response to Mexican President Lázaro Cárdenas’ offer to give shelter to several tens of thousands of Spanish refugees in Mexico. Competition for one of 1,600 spaces on board the ship was intense among Republican refugees, as it was one of the few options some of them had to leave the camps, and the threat of war with German made the possibility of exile in Mexico even more appealing. The selection by SERE of the refugees admitted on board the

\footnotetext{
${ }^{3}$ Children at the refugee centre in Orly published the bilingual (French and Spanish) newspaper El ramillete with the help of the Workers' International. In the camp of Argelès, two refugees named José Atienza and Efrén Hermida published the cultural review Barraca, produced by hand (Scott Soo, The routes to exile: France and the Spanish Civil War refugees, 1939-2009 (Manchester, 2013) at 64, 104 and 107-8). In the realm of music, Basque composer Ramón Muguruza founded in the refugee camp of Gurs a male choir who then travelled to Chile on board the Winnipeg and eventually evolved into the Coro Vasco de Santiago de Chile (Basque Choir of Santiago de Chile).

${ }^{4}$ This is what José Ignacio Cruz Orozco terms 'barracones de la cultura' (barracks of culture'), active in several camps including Gurs, Argelès and Saint-Cyprien; see José Ignacio Cruz Orozco, 'Los barracones de cultura. Noticias sobre las actividades educativas de los exiliados españoles en los campos de refugiados', Spagna contemporanea, 5 (1994), 61-78.
} 
Sinaia caused controversy among the exiled community, as it greatly favoured the Communist Party (Partido Comunista de España, PCE) $)^{5}$ - hegemonic on the Republican side during the Civil War and, subsequently, in exile. ${ }^{6}$ In this context, it is entirely plausible that the members of the Banda Madrid managed to secure places on board the Sinaia because most of them belonged to the PCE. ${ }^{7}$ Given that no member of the Banda Madrid had any significant involvement with the PCE during the Second Republic, it is also likely that most of them only joined the organization around the time of the general election in February 1936 or during the Civil War itself - as was the case with several tens of thousands of Spaniards, attracted precisely by the PCE's perceived hegemony. ${ }^{8}$

The Sinaia soon became a symbol of the plight of the Spanish Republicans and a key site for the early development of Spanish exiled culture and identity; certainly, the early activities of the Banda Madrid were shaped by, while at the same time contributed to, these identity formation processes. The Banda was ubiquitous in the cultural and entertainment activities on board the ship, offering at least one and often two concerts per day, and these were always announced in the on-board newsletter, Sinaia. The ensemble did not play explicitly political or wartime pieces, ${ }^{9}$ but its repertoire did fulfil a political function in that it sought to construct a Spanish exiled identity which would resonate with the common men and women on board the Sinaia. The repertoire indeed coincided with what an average Spanish audience from the working or lower middle classes would have enjoyed listening to in a concert of their local wind band, including some pasodobles by Oropesa himself. A second pillar of its repertoire was wind band arrangements of zarzuela overtures or selections, which had similarly

\footnotetext{
${ }_{5}^{5}$ Soo, The routes into exile, 102; Abdón Mateos, 'Los republicanos españoles en el México cardenista', Ayer, 47 (2002), 103-128 at 101-2

${ }^{6}$ Jorge de Hoyos Puente, 'La formación de la identidad del refugiado: los republicanos españoles en México, discursos, prácticas y horizontes de futuro', Laberintos. Revista de estudios sobre los exilios culturales españoles, 14 (2012), 49-68 at 50. The rise of the party was phenomenal indeed: before the general election of February 1936, it was a rather marginal organization with 30,000 affiliates all over Spain. The party's very active involvement in the pro-Popular Front electoral campaign made its membership rise to 100,000, and the momentum was kept after the Civil War started, with membership reaching 300,000 in June 1937.

${ }^{7}$ The list of passengers on board the Sinaia and other historical records indicate that two belonged to other political parties (Luis Santos Martín to the PSOE, and Narcís Costa i Horts to Esquerra Republicana). For a further three there is no information about their political allegiances.

${ }^{8}$ De Hoyos Puente, 'La formación de la identidad del refugiado', 50.

${ }^{9}$ The concert programmes of the Banda Madrid can be found in the Sinaia newsletter, available online at http://www.cervantesvirtual.com/obra/sinaia--diario-de-la-primera-expedicion-de-republicanos-espanoles-amexico/.
} 
become popular among the least privileged classes between the late 19th and the early 20th century. The third pillar of the Banda Madrid repertoire included arrangements of popular orchestral works and operas by Beethoven, Wagner ${ }^{10}$, Rimsky-Kosakov and Bizet. The numerous mentions to the Banda Madrid in the surviving memoirs of Sinaia passengers and in the on-board newsletter suggest that the ensemble was widely regarded as a force capable of uniting and representing the exiled community as it took shape thanks to its appeal among the common men and women who travelled on board the Sinaia. ${ }^{11}$

This episode of a group of musicians not only fleeing fascism across the Atlantic (as many would do after them in the coming six years, this time from Central Europe), but also making music in the process and, in doing so, shaping their own identity as a group and that of the community they belonged too, is certainly evocative, but in the course of this article I will argue that it is more than that: it also expands our understanding of key questions concerning music and exile in Francoist Spain and, more generally, of music and exile in this era. These key questions are concerned with how we, as music historians, can identify and locate the political: indeed, I follow in the footsteps of literary scholar Mari Paz Balibrea here, who argues that 'it is the task of scholars of exile to 'disentangle the confusion that exists around the political, ${ }^{12}$ because 'the special nature of th[e] exilic corpus (...) has the virtue of making visible discursive contradictions and ideological implications whose influence goes far beyond strictly academic circles. ${ }^{13}$ Whereas Balibrea's 'exilic corpus' consists of the body of literary work (primarily novels) written by exiles, in this article I propose to expand these boundaries, considering not just newly composed works, but also repertoires which acquired new meanings in

\footnotetext{
${ }^{10}$ Even though Wagner's music was substantially appropriated by National-Socialism, this did not lead Spanish exiled musicians to reject his operas (it must be taken into account, though, that a majority of Spanish exiled composers had traditionally felt closer to the French and Russian avant-garde than they did to the Germanic tradition). On the other hand, National-Socialist discourses about Wagner did not substantially influence his reception under Francoism either.

${ }^{11}$ For example, Cecilia Sanz de Ridaura quoted in Pablo Mora and Ángel Miguel Barco en tierra: España en México (Madrid, 2006) at 126; an anonymous female refugee quoted in José Antonio Matesanz, Las raíces del exilio: México ante la Guerra Civil Española (Mexico City, 1999) at 453; Florinda San Agustín Labrada quoted in Dolores Pla Brugat, El aroma del recuerdo: narraciones de españoles republicanos refugiados en México (Mexico City, 2003) at 143; Manuel Andújar and Rómulo García Salcedo quoted in Concepción Ruiz-Funes Montesinos and Enriqueta Tunón, Palabras del exilio 2. Final y comienzo: el Sinaia (Mexic City, 1982) at 77.

${ }^{12}$ Mari Paz Balibrea, 'De los Cultural Studies a los estudios culturales: el caso del exilio republicano', Journal of Spanish Cultural Studies, 11 (2010), 251-262 at 251.

${ }^{13}$ Balibrea, 'De los Cultural Studies', 256.
} 
exile, as well as the careers of musicians, the networks they formed, and the musical practices they engaged in: some of these can indeed tell us about how these musicians conceived of their own and others' Spanish identities, and how they shaped it in a situation of displacement, in the midst of tensions between political factions with different ideas of what Spanish identity consisted of.

My focus on orchestral and band musicians, on the other hand, also expands the boundaries of scholarship on music and exile, which has typically focused on composers - both in other contexts such as Nazi Germany ${ }^{14}$ and in Spain, with Emilio Casares Rodicio, who pioneered the study of Spanish music in exile, asking in $1987:^{15}$

What is still to be done [in the realm of academic research on music and exile in Spain]? We still need shed light on an enormous amount of works that have never been played or have not been played after their premiere; to catalogue the work of most composers (even though it might seem unbelievable that this has not been done already) and to properly analyse it; finally, to write and publish monographs about the most illustrious creatives (autores).

Casares referred to composers as 'autores' (i.e. those who author works), and did not mention performers at all, even though the Spanish Republican diaspora did include at least one performer of international renown (cellist Pau Casals) and others who had key roles within the exiled community (mezzo-soprano Conxita Badia in Argentina, violinist Jesús Dopico and pianist Rosa García Ascot in Mexico). Also missing from Casares Rodicio's research programme were popular musicians, such as prominent copla singers Miguel de Molina and Angelillo, ${ }^{16}$ and lesser-known ones who made a career

\footnotetext{
${ }^{14}$ Brinkmann and Wolff's pioneering edited volume on musicians who arrived in the United States fleeing Nazism; see Reinhld Brinkmann and Christoff Wolff (eds.), Driven into Paradise. The Musical Migration from Nazi Germany to the United States (Berkeley, Los Angeles and London, 1999). The story of Polish violinist Bronislaw Huberman and his efforts to set up the Palestine Symphony Orchestra have garnered some popular attention in recent years, with Josh Aronson's documentary Orchestra of Exiles (2012), followed by Josh Aronson and Denise George, Orchestra of exiles (New York, 2016) - a popular work rather than a scholarly one.

${ }^{15}$ Emilio Casares Rodicio, 'La música española hasta 1939', 263. Translations are my own unless otherwise stated.

${ }^{16}$ Miguel de Molina, one of the most famous copla singers of the twentieth century, first stayed in Spain under Franco but left for Argentina in 1942 after being subjected to harassment and abuse for being a homosexual. He stayed in Argentina until his death in 1993. Angelillo supported the Republic during the Civil War and then took exile in Buenos Aires, although during the 1950s he came back to Spain regularly to appear in a number of copla films.
} 
composing popular music and conducting ensembles, such as Julián Bayod or Crescencio Tapia

Colman. ${ }^{17}$

Casares Rodicio's focus on composers, on the other hand, is consonant with trends within the study of the Spanish Republican exile that have privileged intellectuals, artists and professionals over the working-class masses, under the pretence that the Spanish Republican exile was unique not because of the sheer number of Spaniards who took exile, but rather because of the fact that the most educated layers of society were overrepresented. ${ }^{18}$ In attempting to open up the focus on the intellectual and creative elites that has often dominated scholarship on the Spanish Republican exile, this article inserts itself within a separate current of scholarship that has repeatedly argued that we need to consider less prominent voices and communities too in our attempt at making sense of the Spanish Republican Exile. ${ }^{19}$ Of course, in the musical realm it would not be accurate to divide musicians between an 'elite' of composers and a 'mass' of orchestral and wind band performers: some

\footnotetext{
${ }^{17}$ Sources to track down the careers of these musicians are extremely scarce: Bayod started working as a wind band conductor still in his teens in Spain, and he published popular music in Mexico, after which he died prematurely. Crescencio Tapia Colman was active in his brother Simón's (also a classical composer who exiled in Mexico) jazz band during the 1920s and 1930s, and settled in Mexico in the mid-1940s, where he also published popular music. For additional information, see Eva Moreda Rodríguez, 'Sobre la necesidad de estudiar a los músicos de orquesta y de banda en el exilio: reflexiones a partir de cinco perfiles del exilio republicano español en México', in David Ferreiro and Nicolás Rincón, Bandas de música: contextos interpretativos y repertorios (Madrid, forthcoming in 2018).

${ }^{18}$ Works which implicitly or explicitly make this claim include: Alicia Alted, La voz de los vencidos. El exilio republicano de 1939 (Madrid, 2005) at 257-8; José Luis Abellán, El exilio español de 1939 (Madrid, 1976) at 23; José Luis Abellán, De la Guerra Civil al exilio republicano (1936-1977) (Madrid, 1983) at 59.

${ }^{19}$ Such as: Francisco Caudet, El exilio republicano de 1939 (Madrid, 2005) at 57; Milagrosa Romero Samper, La oposición durante el franquismo/3. El exilio republicano (Madrid, 2005) at 18; Eugenio Fernández Granell, 'Exilio partido en dos', in José María Naharro Calderón (ed.), 1991. El exilio de las Españas de 1939 en las Américas: ‘¿Adónde fue la canción?' (Barcelona, 1991), 133-143 at 133. Journalistic works on the Spanish Republican Exile and those intended for a broader, non-academic audience have tended to show greater awareness of the so-called common men and women among exiles, including, in some cases, orchestral musicians and non-professional music-making, such as Carlos Martínez, Crónica de una emigración. La de los republicanos españoles en 1939 (Mexico City, 1959) at 63 and 92 (Martínez claims here that the Banda Madrid was founded in Mexico, which is incorrect) and Patricia W. Fagen, Exiles and Citizens. Spanish Republicans in Mexico (Austin and London, 1973) at 39.
} 
individuals (Narcís Costa i Horts ${ }^{20}$, Luis Hernández Bretón ${ }^{21}$, Simón Tapia Colman ${ }^{22}$ ) moved back and forth between both occupations, and, while orchestral and band musicians were closer to the working class movement under the Second Republic than most composers were, some orchestral musicians (cellist Luis Santos Martín, subsequently a member of the Banda Madrid) came from a middle-class background, and a few composers (Josep Valls, ${ }^{23}$ Simón Tapia Colman) came from working-class milieus.

\section{The Antecedents. The Second Republic and the Civil War.}

The ways in which the Banda Madrid came to embody and transmit certain aspects of Spanish exiled identities and did so differently from classical composers in exile are closely connected to antecedents during the Second Republic and the Civil War. Therefore, in this section I will briefly discuss this previous historical period. Key here are the concepts modernity and modernization, which are profoundly connected to the political in the context at hand: indeed, the Spanish Second Republic was largely conceived by its supporters as a modernizing project, aimed at diminishing the influence of the forces that had been traditionally hegemonic in Spain (the Catholic church, the army, the landowners) and implementing a modern, European democracy. Importantly, the Republic was seen as a modernizing project by its detractors too: right-wing sectors, in supporting or justifying Franco's

\footnotetext{
${ }^{20}$ Narcís Costa i Horts was, before the Civil War, a clarinettist and composer of both cobla (a traditional Catalan music genre) and art music. During the war, Costa i Horts was employed by the Catalan government as a music teacher; after the fall of Catalonia, he fled to the French border and was interned in Le Barcarès, where he met the Banda Madrid and then travelled with them to Mexico. He conducted the Orfeó Catalá de Mèxic there and premiered his second symphony in Mexico City in 1944 and his suite Historieta musical in Acapulco in 1960. See Lluís Brugués i Agustí and Elisenda Vidal i Comellas, 'El llarg exili de Narcís Costa-Horts', in Revista de Girona 266 (2011); 50-2 at 50-1.

${ }^{21}$ Hernández Bretón worked as a cellist in Madrid orchestras before the Civil War. He started to compose while temporarily in exile in Toulouse, and during his early years in Mexico he combined both, playing for the Orquesta Sinfónica and conducting for radio stations, until he left the cello in favour of a career as a film music composer. See Gabriel Pareyón, Diccionario de Música en México, vol. 1 (Guadalajara, 1995) at 486.

${ }^{22}$ Tapia Colman worked as an orchestral violinist and jazz band leader before the Civil War, while at the same time composing his first classical works. In exile in Mexico, he found his first job as a violinist at the Orquesta Sinfónica de México and then moved on to a range of musical activities including choral conducting, teaching, arranging stage music and composing both ballet and orchestral music

${ }^{23}$ Born in Barcelona in 1904 to a family who had emigrated from the Catalan countryside from Barcelona, Valls first exiled in 1924 to Paris and then Anvers to escape from completing military service in Spain. He returned to Catalonia to fight with the Republican army, after which he took exile in Le Havre. The author of an extensive oeuvre spanning from art song to orchestral pieces, most of his music is now unpublished and unrecorded.
} 
coup, largely used the argument that modernization had gone too far (for example, with the marginalization and even open attacks to the Catholic church supported by left-wing Republican governments). When the Civil War finished, the Second Republic was largely conceptualized in exile as a failed project of modernization. ${ }^{24}$ Nevertheless, as Mari Paz Balibrea remind us in another article, we should not lose sight of the fact there was not a single, uniformized modernizing project behind the multiplicity of factions and individuals (from moderate liberals to anarchists) who supported the Republic; instead, several projects coexisted both in Spain under the Republic and then abroad, which -she further claims - the historiography of exile has not always accounted for, thus obscuring the political side of the refugees' trajectories. ${ }^{25}$

Music under the Second Republic and then in exile was also subjected to similar tensions around modernization: in fact, not all musicians who supported the Republic in one way or another agreed on what measures needed to be taken to modernize Spanish music (which could in itself mean vastly different things, from the musical language that should be adopted by Spanish composers to more pragmatic issues regarding musicians' salaries or the curriculum to be taught at conservatoires). Although differences between modernizing projects did not always express themselves under the form of open, simplistic conflict, the Second Republic, as a highly politicized environment, indeed saw instances of hostility between two modernizing projects which were then translated, in different ways, into exile: that of unionized orchestral musicians, on the one hand (the main ground from which the Banda Madrid recruited its members) and that of composers pertaining to what we might call the middle-class, liberal left in Madrid, on the other. A number of these composers attempted to implement their modernizing project through the Junta Nacional de Música y Teatros Líricos (National Board for Music and Opera/Zarzuela Theatres), set up shortly after the beginning of the

\footnotetext{
${ }^{24}$ Mari Paz Balibrea, 'Rethinking Spanish Republican Exile. An introduction', Journal of Spanish Cultural Studies, 6 (2005), 3-24 at 3-4. Following Balibrea, I understand modernity here as 'a way of conceiving time which totalizes history and time from the point of view of a present conceived as always new, always on the verge of disappearing, and therefore transitory, ephemeral and fragmentary' (Mari Paz Balibrea, 'Rethinking Spanish Republican Exile', 7).

${ }^{25}$ Sebastiaan Faber and Cristina Martínez-Carazo, 'Problemas y paradojas del exilio español en Estados Unidos', in Sebastiaan Faber and Cristina Martínez-Carazo (eds.), Contra el olvido. El exilio español en Estados Unidos. (Alcalá de Henares, 2010), 9-26 at 12; Helena López, 'Exilio, memoria e industrias culturales: esbozo para un debate', Migraciones y Exilios, 5 (2004), 25-36 at 27-8.
} 
Second Republic in 1931, with the aim of reorganizing Spanish musical life, focusing particularly on the re-opening of the Teatro Real and the setting up of a national orchestra. Only three members of the Junta were not composers: two were orchestral conductors and one, Adolfo Salazar, was a music critic. Salazar quickly became, together with president Óscar Esplá and secretary Salvador Bacarisse, one of the most visible and active members of the Junta. Since the three were part of the middle-class, liberal, somewhat elitist left I have mentioned earlier, a significant sector of the music profession came to identify the Junta with this political faction - and those who did included conservative composers such as Manuel de Falla, Federico Moreno Torroba and Joaquín Turina, who were all among the original membership of the Junta but eventually resigned after having become disenchanted with the liberal faction's hegemony. ${ }^{26}$

Orchestral musicians, on the other hand, unionized under the Asociación de Profesores de Orquesta de Madrid. This was initially founded in 1901 as a mutual aid society, but by the inception of the Second Republic it had become integrated into the general trade union Unión General de Trabajadores (UGT), which was in turn connected to the Spanish socialist party, the PSOE. The Asociación's move was part of a reorganization of UGT aiming at setting up a more centralized, transregional structure encompassing workers from all industries. ${ }^{27}$ The list of passengers on board the Sinaia indicates that the overwhelming majority of members of the Banda Madrid were members of UGT during the Civil War (see table 1), but this does not mean that all of them were already unionized during the Second Republic; indeed, it is plausible that some only joined UGT when unionization became compulsory during the war. We do know that some of them were active in the Asociación during the Second Republic; similarly, with Asociación gaining in significance and becoming radicalized throughout the Second Republic because of the increasingly politicized climate and of the pressing unemployment

\footnotetext{
${ }^{26}$ A critical history of the Junta's history is still to be written; the above summary is based on José Subirá's unpublished account of the Junta's history, totalling more than 1,000 pages (José Subirá, La Junta Nacional de Música y el Teatro Lírico. Historia crítica, ca. 1935, unpublished manuscript held at the Biblioteca Nacional de España). Subirá goes into forensic detail and includes numerous press clips as well as testimonies from critical members of the Junta: these indeed suggest generalized discontent with Esplá's leadership, as do the press sources coming from the unionized orchestral musicians' environment that will be discussed subsequently. Nevertheless, we should not lose sight of the fact that Subirá was motivated by bitter personal rivalries with Esplá, Salazar and Bacarisse, hence the need for further critical examination of this source.

${ }^{27}$ Manuel Redero San Román, 'La problemática de la organización de la UGT en la II República', Studia historica, 1 (1983), 67-87 at 74.
} 
problem about musicians, ${ }^{28}$ we can presume that other future members of the Banda also joined or at least sympathized with the Asociación.

The Asociación's modernizing project for Spanish music focused mostly on labour issues. While it claimed that musicians' work was of a more elevated nature than manual professions, ${ }^{29}$ it saw musicians essentially as workers exploited by capitalism, as those in any other sector, and claimed that musicians should therefore unionize as a matter of priority. ${ }^{30}$ The Asociación advocated for hardline socialism and argued that the state should take over the music industry (and all other industries, for that matter) and subsequently pass it over to the proletariat, which would guarantee that both the labour and the artistic aspirations of musicians were fulfilled. ${ }^{31}$

On the other hand, the modernizing projects of the Junta, focused on restructuring musical life and make canonic repertoires and new music more accessible to Spanish audiences, did not address the Asociación's concerns, with criticisms from the latter surfacing as early as the Junta was founded in June 1931 for having been set up without consulting with the music profession (that is, orchestral musicians) $)^{32}$ and doing little to alleviate unemployment - then the most pressing problem for orchestral musicians. ${ }^{33}$ A 1934 interview with Esplá in the newspaper El heraldo de Madrid exemplifies the disconnect that existed between the modernizing programmes of the Junta and the Asociación: when asked about the Junta's plans to tackle unemployment, Esplá reiterated that this was the Ministry of Labour's responsibility and not the Junta's, but he admitted he would spare a thought

\footnotetext{
${ }^{28}$ Although there are no data specific to the Asociación, the Federación Federación Nacional de Trabajadores del Espectáculo, of which the Asociación was a subset, went from 3,400 members in 1930 to 8,000 by mid1932. See anonymous 1932, 31. Fort he general evolution of UGT during these years, see Santos Juliá, 'La UGT de Madrid en los años treinta: Un sindicalismo de gestión', Reis: Revista Española de Investigaciones Sociológicas 20 (1982), 121-151 at 126 and 144.

${ }^{29}$ Anonymous, 'Compañeros, jsalud!', P.O.M. (1935), 1-4 at 3; Anonymous, 'Compañeros, ;salud!', 4.

${ }^{30}$ F.P., 'Orientaciones', P.O.M., 2 (1935), 5-6; [no first name] Baroni, ‘¿A qué esperamos?', P.O.M., 4 (1935), 10.

${ }^{31}$ F.P., 'Orientaciones', P.O.M., 4 (1936), 5-6.

${ }^{32}$ Anonymous, 'La Junta Nacional de Música y Teatros Líricos. Protesta de la Sociedad de Autores', El Heraldo de Madrid, 27 June 1931, 5; anonymous, 'La Junta Nacional de Música y Teatros Líricos, Ritmo, 35 (1931), 3; Anonymous, 'El primer congreso de la Federación Española de Espectáculos inaugura sus trabajos', Ahora, 12 July $1932,31$.

${ }^{33}$ Anonymous, 'Conferencia nacional sobre la crisis musical', Ritmo, 36 (1931), 3-4; Anonymous, 'Peibiscito Nacional de Profesores de Orquesta', Ritmo, 42 (1931), 10-1; Anonymous, 'El primer congreso de la Federación Española de Espectáculos inaugura sus trabajos', Ahora, 12 July 1932, 31.
} 
for the families of struggling Spanish musicians when attending the opera performances organized by the Junta. ${ }^{34}$ Criticisms of the Junta continued after it was disbanded in 1933 by the newly elected right-wing government. ${ }^{35}$

Nevertheless, even in the politically radicalized climate of the Second Republic there were modernization issues on which the Junta's leaders and the Asociación's unionized musicians could agree. For example, P.O.M., the Asociación's newsletter, invited Salvador Bacarisse in 1936 to write a guest article, and Bacarisse used the occasion to complain that Prokofiev was played scarcely in Spain, instead of Haendel, Bach and Debussy. ${ }^{36}$ (Bacarisse 1936: 5-6). We might imagine that Bacarisse was being strategic here in which concerns his involvement with the Asociación: instead of choosing a controversial topic, such as unemployment, he wrote on a subject (the dissemination of more or less accepted forms of new music) that him and orchestral musicians could agree on. Subsequently, the Civil War's 'wartime culture' ${ }^{37}$ also eroded some of the differences between these modernizing programmes, with a significant part of the Asociación's energies now dedicated to supporting the war effort both in the front and the home front and unemployment not being such a pressing issue: competition for jobs was reduced as many musicians volunteered to go to the front and, thanks to compulsory unionization and the increasing power of trade unions in the Republican side, the Asociación (and similar trade unions, such as the CNT-affiliated Sindicato de la Industria del Espectáculo in Barcelona) was able to exert considerable power in terms of organizing and distributing paid work among its members. ${ }^{38}$ Open hostility between the Asociación and the Junta's

\footnotetext{
${ }^{34}$ E. Ruiz de la Serna, 'La Junta Nacional de Música, la próxima temporada de ópera rusa y el hambre de los artistas españoles', El Heraldo de Madrid, 20 February 1934, 4.

${ }^{35}$ Anonymous, 'Ópera en Madrid o en el Calderón nos encontraremos', P.O.M., 5 (1936), 3; F.P., 'Orientaciones', 5-6.

${ }^{36}$ Salvador Bacarisse, Salvador, 'Conciertos', P.O.M., 3 (1936), 5-6. The choice of Prokofiev is not a straightforward one: certainly, he cannot be regarded as one of the main references for Bacarisse or the Grupo de los Ocho in their modernizing effect (although Bacarisse's series of piano preludes Veinticuatro preludios, from 1946, certainly shows some influence from Prokofiev). Nevertheless, he was a respected contemporary composer in the Grupo de los Ocho environment (unlike, say, Schoenberg), and it is likely that Bacarisse named him because other composers that him and the Grupo certainly regarded as key references (Stravinsky, Debussy, Falla) were performed in Madrid, if not often, at least with certain regularity.

${ }^{37}$ I use this in the sense of Abellán, who claims that a wartime culture bearing some resemblances, but also profound differences, with respect to cultural products and institutions before the war. Abellán, De la Guerra Civil, p. vii.

${ }^{38}$ Anonymous, 'La Asociación de Profesores de Orquesta', La libertad, 26 July 1936, 12; Anonymous,

'Conciertos', La libertad, 13 September 1936, 12; Anonymous, 'La Asociación de Profesores de Orquesta',
} 
successor (the Consejo Central de la Música, established in July 1937) ceased, even though all appointees to the Consejo were composers, conductors or musicologists, including Bacarisse (Salazar and Esplá had left Spain by then). Orchestral musicians were absent from management positions, even though one of the Consejos' flagship projects was the setup of a symphony orchestra, suggesting that differences between modernizing projects and interests survived.

\section{The Banda Madrid in Mexico}

There is no evidence that tensions between exiled composers and the Banda Madrid (or orchestral and band musicians more generally) still existed in exile. Rather, the Banda Madrid seemed to inhabit a separate world from composers: composer and musicologist Jesús Bal y Gay, also exiled in Ciudad de Mexico, did not mention the Banda Madrid once in his memoir, even though he covered the exiled musical community at length ${ }^{39}$, and there is no sign than any of the numerous composers and musicologists in the same city (Rodolfo Halffter, Baltasar Samper, Gustavo Pittaluga, Otto MayerSerra) engaged with the Banda either. Some exiled composers and musicologists, including Esplá, Bacarisse and Salazar, were concurrently engaging more or less actively in the shaping of Spanish exiled identities: Esplá, before returning to Spain in 1950, corresponded with other exiled composers to re-organize in exile the Spanish section of the International Society for Contemporary Music ${ }^{40}$, whereas Bacarisse tried to collect works from fellow composers and forward them to Spanish performers so that the music of the exiles was performed in Spain. His project failed principally because other composers were disinterested, but he did manage to have several of his own works performed in Francoist Spain. ${ }^{41}$ Adolfo Salazar was not so active in taking leadership positions (in Ciudad de México, he needed to produce written material on music at a fast pace in order to make a living), but was widely regarded among the exiles and also in some sectors of Francoist Spain as the

Ahora, 1 August 1936, 8; Anonymous, 'Conciertos', La libertad, 13 September 1936, 12; Anonymous, 'La Asociación de Profesores de Orquesta', Ahora, 1 August 1936, 8.

${ }^{39}$ Jesús Bal y Gay and Rosa García Ascot, Nuestros trabajos y nuestros días (Madrid, 1990).

${ }^{40}$ Moreda Rodríguez, Music and exile in Francoist Spain, 91-2.

${ }^{41}$ Moreda Rodríguez, Music and exile in Francoist Spain, 63-70. 
ultimate authority on Spanish contemporary music. ${ }^{42}$ In the meanwhile, and separately, the Banda Madrid was also contributing to shaping Spanish identities in exile, and indeed its activities and trajectory in Ciudad de México mirror the tensions which shaped the Spanish exiled community in Mexico in its initial years in a way that the trajectories of exiled composers do not. We can also presume that their performers arrived to greater numbers of exiled Spaniards.

The Banda Madrid was active from 1939 to 1947, and performed mostly at events of a political or cultural nature organized by the Spanish exiled community. Some of its musicians occasionally appeared under the names of Orquesta Iberia and Orquesta Hispania at events of a more festive or commercial nature. ${ }^{43}$ The repertoire of the Banda Madrid stayed practically the same as it was on board the Sinaia, with the addition of national anthems (Spain, Mexico, France, Euskadi, Catalonia) in events specifically aimed at celebrating one or more of these countries. The meanings of the Banda's repertoire, though, could fluctuate flexibly, and in the early years of exile in Mexico, the Banda Madrid variably appeared as a symbol of Spanishness, broadly understood, as a symbol of the antiFrancoist/Republican/democratic Spain, or (more rarely) as a symbol of a particular subset within the Spanish exiled community: the Communist Party ${ }^{44}$ Moreover, two or all three of these connotations could appear in combination and under different forms. This must be understood in the context of the identity formation processes in the early years of exile described by De Hoyos Puente. ${ }^{45}$ De Hoyos Puente discusses how a new symbolic and discursive framework had to be developed quickly, and this involved developing both a sense of who the exiles were and where they came from qua exiles and qua Spaniards, but it also involved defining oneself as part of one of the various factions within the Spanish exiled community.

\footnotetext{
${ }^{42}$ Moreda Rodríguez, Music and exile in Francoist Spain, 139-47.

${ }^{43}$ Pla Brugat, El aroma del recuerdo, 35.

${ }^{44}$ Interestingly, the mention to Madrid in the name of the ensemble does not seem to have been read by the exiled community as centralistic or anti-Catalan: it is likely that it was regarded simply as the birthplace of the Banda's conductor and of most of his members.

${ }^{45}$ De Hoyos Puente, 'La formación de la identidad', 50; Jorge de Hoyos Puente, 'Discrepancias entre patriotas: ideas de estado en los imaginarios políticos del exilio republicano en México, 1939-1950', Migraciones y Exilios, 13 (2012), 11-32 at 13.
} 
The early history of the Spanish Republican Exile in Mexico indeed saw widespread divisiveness; if anything united the different factions, it was solely their generalized hate of the Franco regime. The divisions in exile mirrored to an extent the ideological and practical differences between the political parties of the Republican side during the Spanish Civil War (PSOE, PCE, anarchists, the liberal left, etc.), but contributing to the rivalries were too the perceived responsibilities for the Republic's defeat: the last president of the Republic, the socialist Juan Negrín, was regarded as a traitor by many in his own party, but was at the same time supported by former communists. ${ }^{46}$ It is likely that it was because of this climate of divisiveness that the Banda Madrid performed only very rarely in the years 1939-1941, with only one performance recorded in España popular, the newspaper of the exiled community in Mexico, at an a homage to Mexican president Lázaro Cárdenas at the end of his tenure in December $1940 .{ }^{47}$ Loyalty to Cárdenas was indeed one of the few things that could unite the different factions in exile: Cárdenas was one of the few international leaders to offer practical and moral support to the Spanish Republic, as part of the process of international self-reaffirmation of post-revolutionary Mexico. ${ }^{48}$

Significantly, the activities of the Banda Madrid became more frequent after the discourse of unidad (unity) started to develop within the exiled community in Mexico. As early as April 1940, the parties Unión Republicana and Izquierda Republicana founded Acción Republicana Española in order to coordinate anti-Franco activities, although this initial attempt only had limited success as no other parties joined. ${ }^{49}$ Nevertheless, the development of the Second World War during 1941, with the Operation Barbarossa starting in June and the United States joining the war in December, nurtured a certain optimism among the Spanish exiled community that the Allies would help them defeat Franco,

\footnotetext{
${ }^{46}$ De Hoyos Puente, 'Discrepancias entre patriotas', 16; Jorge De Hoyos Puente, Jorge, 'La evolución del negrinismo en el exilio republicano en México', Historia y política, 36 (2016), 313-337 at 316; Pablo Jesús Carrión Sánchez, 'La delegación del PCE en México (1939-1956). Origen y límite de una voluntad de liderazgo de la oposición', Espacio, tiempo y forma, 16 (2004), 309-336 at 310.

${ }^{47}$ Anonymous, 'Un homenaje de los republicanos españoles al General Cárdenas', España popular, 7 December 1940,6 .

${ }^{48}$ Mateos, 'Los republicanos españoles', 110 and 128; Jorge De Hoyos Puente, 'México y las instituciones republicanas en el exilio: del apoyo del Cardenismo a la instrumentación política del Partido Revolucionario Institucional, 1939-1977', Revista de Indias, 260 (2014), 275-306 at 275 and 278.

49 De Hoyos Puente, 'Discrepancias entre patriotas', 20-1.
} 
and this in turn encouraged some factions to launch initiatives to promote unity. ${ }^{50}$ The PCE started a broad anti-fascist front called Unión Nacional in 1941, which had moderate success, but the Communists did not join the Junta Española de Liberación set up by Diego Martínez Barrio on $25^{\text {th }}$ November $1943^{51}$ (although some members of the PCE did support the Junta individually). The second conference of the Spanish Republican exile, held in Toulouse in August 1944, further encouraged unity among the different factions. ${ }^{52}$

During these years, the Banda became a regular in events that could appeal to all factions, such as the celebration of May Day - which most political groups in exile celebrated, unlike other dates that were specific to individual parties ${ }^{53}$ - and events aiming at fostering a sense of community among all Spaniards in Mexico, whether they were exiles or had arrived in Mexico before the Civil War. ${ }^{54}$ Expressions of loyalty to Mexico continued, with homages to Cárdenas's successor, Manuel Ávila Camacho, also supportive to the Spanish Republicans. ${ }^{55}$ This, however, did not prevent the Banda Madrid from occasionally becoming involved in other activities more akin to their allegiance to the PCE, such as events aiming at honouring Communist leaders, such as Pedro Checa ${ }^{56}$ and Jesús Larrañaga. ${ }^{57}$ The Banda Madrid also set up a 'círculo de estudio' (study circle) for its own members in response to an initiative launched by the PCE in Mexico. Círculos de estudio consisted on regular meetings for the discussion of readings aimed at improving their members' political education. ${ }^{58}$

The Banda itself soon became a living example of unidad. In an event in May 1943 aimed at paying homage to the Banda itself, trade union leader Daniel Anguiano, praised the example of "narrow and immutable unit [set by] this musical ensemble, who, formed by men from all political trends, is kept

\footnotetext{
${ }^{50}$ De Hoyos Puente, 'Discrepancias entre patriotas', 23.

${ }^{51}$ Xavier Flores, 'El Gobierno de la República en el exilio. Crónica de un imposible retorno', Espacio, Tiempo y Forma, 14 (2010), 309-350 at 311; Carrión Sánchez, 'La delegación del PCE', 316.

52 De Hoyos Puente, 'La evolución del negrinismo', 328-30.

${ }^{53}$ De Hoyos Puente, 'Discrepancias entre patriotas', 17.

${ }^{54}$ Anonymous, 'Centenares de mexicanos y españoles de la vieja y nueva emigración asistieron al baile a beneficio de la 'Banda Madrid', España popular, 29 August 1942, 4.

55 Anonymous, ‘Actuación de la Banda Madrid y del Coro Vasco', España popular, 2 April 1943, 3

${ }^{56}$ Anonymous, 'La guardia al cadáver y el entierro de Pedro Checa constituyeron una emocionante y viva expresión de condolencia', España popular, 12 August 1942, 2.

57 Anonymous, 'La velada en homenaje a Jesús Larrañaga', España popular, 11 September 1942, 3.

${ }^{58}$ Anonymous, Final del pleno', España popular, 7 June 1946, 4.
} 
united by their love to Spain and by its spirit of fight against Francoism' ${ }^{59}$ Anguiano's claim that the Banda was made up of men from all political trends is clearly exaggerated if we take into account that an overwhelming majority of them belonged to the PCE. It is likely, though, that the widespread metaphor of music as a universal language and the orchestra (or ensemble) as an example of several individuals working together towards a common goal played a role in how the Banda Madrid was perceived among the exiled community. The Banda itself were keen to appear as an example of unidad: in an assembly in 1946 where various factions and groups from within the exiled community debated joint action against Franco, French horn player Martín San José spoke of the Banda Madrid as an 'organism of unity. ${ }^{90}$ It was also the Banda as an ensemble, as opposed to its individual members, which adhered to a number of initiatives aimed at unity of action against Franco ${ }^{61}$; among those was the Junta Suprema de Unidad Nacional in April $1944 .{ }^{62}$ This was unusual: exiles tended to adhere to such organizations individually or grouped in regional or local associations (e.g.

Galician/Madrilenian/Catalan/Basque exiles).

The Banda's profile among the exiled community was also kept high by its members' commitment to fundraising for a number of causes, such as the funding of an ambulance ${ }^{63}$ and collecting money to support anti-Franco activities by those who had stayed behind in Spain. ${ }^{64}$ Compared to other groups within the exiled community, the Banda's fundraising activities were very successful. Particularly prominent was the Banda Madrid's contribution to the Fondo Cristino García, set up in 1946 with the aim of helping anti-Franco militants fighting clandestinely in Spain. The Fondo aimed to fundraise 500,000 pesos in three months when it first appeared in 1946, with the Banda Madrid being one of the most active groups. ${ }^{65}$

\footnotetext{
${ }^{59}$ Anonymous, 'El gran festival de Bellas Artes', España popular, 7 May 1943, 3.

${ }^{60}$ Jesús Rozado, 'Algunos resultados logrados en el estudio y la educación política en el Partido', España popular, 16 August 1946, 5.

${ }^{61}$ Anonymous, 'Información final sobre el V Pleno en México', España popular, 16 May 1947, 2.

62 Anonymous, 'Adhesiones en México a la Junta Suprema', España popular, 7 April 1944, 5.

63 Anonymous, 'La última lista pro-ambulancia', España popular, 3 January 1942, 3.

${ }^{64}$ Anonymous, 'Los comunistas españoles en México recaudan 15.000 pesos para sus camaradas en España', España popular, 14 July 1944, 3.

${ }^{65}$ Anonymous, 'Fondo Cristino García', España popular, 26 April 1946, 5; Wenceslao Roces, ‘¡Hacia los 500.000 pesos!', España popular, 14 June 1946, 5.
} 
The Banda Madrid's activities in support (moral and financial) of unidad suggest that its musicians were content to develop its profile as 'Spanish' and 'modern' (i.e., democratic and anti-Francoist) within the constraints of the official discourse of the Spanish exile in Mexico. This crucially involved not interfering or commenting on Mexican internal politics. It has been repeatedly pointed out in scholarship there was among exiles a sense that to stay loyal to Mexico and the Mexican government (by refraining from voicing any sort of criticism) meant to stay loyal to Spain and the Second Republic. This led to the apparent contradiction that many exiles who had been very politically active while in Spain now refrained from making any political utterances in respect of their host country. ${ }^{66}$ The Banda itself, as well as its individual members, fell within this category: indeed, for all of its activity among exiled circles, it kept a low profile in Mexican internal affairs, and its correspondence with Mexican trade unions was limited to seeking moral support in the anti-Franco struggle. ${ }^{67}$

The discourse of unidad dwindled after the end of the Second World War, as it became clear that the Allies would not lend their support to Spanish exiles to overthrow Franco. Relations between Spain and the United States then became normalized later in the $1940 \mathrm{~s} .{ }^{68}$ In this climate, it is not surprising that the Banda Madrid did not survive for long. Contributing to the dismantlement of the Banda were other factors: its conductor, Rafael Oropesa, died in exile in October 1944 at the age of just fifty-one. Pedro García Mendizábal, a flute and piccolo player at the Banda, took over, but accounts suggest that Oropesa's absence was acutely noted among audiences ${ }^{69}$ - and possibly among musicians too. Moreover, it is likely that many of the musicians became side-tracked by their other musical commitments: a few of them gained employment during these years with Mexican symphony orchestras, while others were employed in the radio, TV and by popular music ensembles. Others held non-music jobs, such as Fernando Ríos, who worked in the metal industry.

\footnotetext{
${ }^{66}$ Juan Carlos Pérez Guerrero, 'Espacios, dinámicas y discursos en el exilio republicano en México', Studia Zamorensia, 6 (2002), 317-335 at 333; Sebastiaan Faber, 'Silencios y tabúes del exilio español en México', Espacio, Tiempo y Forma. Serie V. Historia Contemporánea, 17 (2005), 373-389 at 375 and 377; Carrión Sánchez, 'La delegación del PCE', 331.

${ }^{67}$ Anonymous, 'Vida de partido', España popular, 23 August 1946, 6.

${ }^{68}$ Carrión Sánchez, 'La delegación del PCE', 310; Flores, 'El Gobierno de la República', 311 and 314-6; De Hoyos Puente, 'México y las instituciones republicanas', 234-5.

${ }^{69}$ Simón Tapia Colman, Música y músicos de México (Mexico City, 1991) at 123.
} 


\section{Conclusion}

By way of conclusion, I would like to list four areas in which I believe the above discussion of the Banda Madrid contributes to expanding current understandings of music and exile in Francoist Spain and in other contexts by allowing us to fine-tune how we identify the political and also expand the realms in which we locate it. Firstly, the study of the Banda Madrid's activities in Mexico and their lack of interaction with composers expands our understanding of the different musical worlds and spheres at work in the exiled community of musicians. These often existing in parallel rather than in synergy and engaged in attempts at building their own legitimacy to represent Spain and Spanish music, sometimes independently of each other, sometimes in conflict. I suggest that the strategies used by the Banda Madrid in Mexico should be considered side-by-side with Bacarisse's attempts at bringing back the music of the exiles into Spain ${ }^{70}$, Esplá's failed attempts at reconstructing the Spanish section of the ISCM in exile ${ }^{71}$, and the Catalan composers' attempts to do the same with the Catalan section years later. ${ }^{72}$ They should also be studied side-by-side with the experiences of other musicians, either composers or performers, who were excluded from or chose not to participate in these legitimizing practices, such as Simón Tapia Colman until rather late in his career. These issues can similarly be translated into the study of music and exile more broadly, for example in which concerns the diverse attitudes of German and Austrian exiled composers and performers vis-à-vis their own canon, whether they considered it primarily a Germanic or universal canon and how they engaged with it while abroad. ${ }^{73}$

\footnotetext{
${ }^{70}$ Eva Moreda Rodríguez, Music and Exile in Francoist Spain (Farham, 2015), 65-6.

${ }^{71}$ Moreda Rodríguez, Music and Exile, 91-2.

${ }^{72}$ No scholarly studies have been published as of yet, but the correspondence of Josep Valls with Baltasar Samper and Roberto Gerhard, held at the Biblioteca Nacional de Catalunya - Fons Josep Valls, is a key source for the study of these issues.

${ }^{73}$ Ernest Krenek, recently fled from Austria, made the following poignant statement in the 1939 London meeting of the International Society for Contemporary Music: 'It was the quality of universalism in the Austrian composer which had given Austria its place in music through the centuries. Perhaps this very quality might make it a little less hard for the Austrian than for others to make his home all over the world' (anonymous, ICSM. Minutas de la conferencia en Londres, unpublished manuscript held at the Fons Robert Gerhard, Institut d'Estudis Vallencs, Valls, Catalonia). An article which engages with a composer's musical reflections on his
} 
Secondly, the formation and synergies of these different worlds and scenes must be studied with reference to broader political developments both diachronic and synchronic, going back to the Second Republic and, some cases, earlier. However, we should be wary of uncritically assuming that all political issues found a perfect counterpart among musicians: for example, we should not assume that the fragmentation between the Banda Madrid on the one hand and the exiled composers on the others mirrors exactly the fragmentation between the PCE and other factions: whereas some composers sympathized with other factions (e.g. Simón Tapia Colman with anarchism), they did not necessarily articulated a musical-political position comparable to that of the Banda Madrid. Moreover, other composers, such as Rodolfo Halffter indeed sympathized with the Communist Party, whereas others were unaffiliated. Parallels can be found with other exile contexts, such as the ways in which differing views of German national identity that the historiography of exile matched, more or less explicitly, different political positions in the Federal and Democratic Republic of Germany, respectively. ${ }^{74}$. Thirdly, we should not regard these different worlds and scenes as self-contained and impermeable. As mentioned earlier, some individuals, such as Narcís Costa and Simón Tapia Colman belonged to at least two of them in different moments of their lives, or even simultaneously; further research could focus on how individuals as the above-mentioned and others navigated such tensions, which are of course to be found in other exiled communities too, with Central European and Soviet composers being required to take on a multiplicity of musical jobs which connected them to each other in different ways.

Lastly, the study of the repertoire of the Banda Madrid should lead us to consider how the formation and development of these different worlds and scenes impinged existing or new repertoires with political meanings that might seem impenetrable to us nowadays. The study of such repertoires must be considered side by side with other repertoires whose political meanings have been disentangled by

own national identity is Andrea F. Bohlman and Florian Scheding, 'Hanns Eisler on the move: Tracing mobility in the 'Reisesonate', Music and Letters, 96 (2015), 77-98.

${ }^{74}$ Florian Scheding, "'The splinter in your eye": uncomfortable legacies and German exile studies', in Music and Displacement: Diasporas, Mobilities and Dislocations in Europe and Beyond (Lanham, 2010), 119-134. 
scholarly research in recent years - as is the case, in other exile contexts, with genres such as film music. $^{75}$

${ }^{75}$ Ben Winters, Erich Wolfgang Korngold's The Adventures of Robin Hood: A Film Score Guide (Lanham, 2007); Sally Bick, 'Political ironies: Hanns Eisler in Hollywood and behind the Iron Curtain', Acta Musicologica, 75 (2003), 65-84. 
Table 1

Sources used in compiling this table include: the list of passengers on board the Sinaia (available online at the site of the Fundación Pablo Iglesias at: http://www.fpabloiglesias.es/sites/default/files/docsbio/sinaia.pdf); the Ibero-american Migratory Movements portal of the Subdirección General de los Archivos Estatales del Ministerio de Educación, Cultura y Deporte of Spain, available online at

http://pares.mcu.es/MovimientosMigratorios/staticContent.form?viewName=presentacion; Simón Tapia Colman's book Música y músicos en México

(Mexico City: Panorama, 1991); concert programmes of the Asociación Musical Manuel M. Ponce, Orquesta de Cámara de México, Orquesta Sinfónica Nacional de México; the following periodical publications: ABC, El Adelanto, Boletín Oficial de la Provincia de Guadalajara, España Popular, Gazeta de Madrid, El Informador, La Libertad, Mujeres Españolas, Mundo Obrero, El Noticiero Gaditano, P.O.M., Ritmo, El Siglo Futuro.

\begin{tabular}{|c|c|c|c|c|c|c|}
\hline Name & Instrument & $\begin{array}{l}\text { Professional } \\
\text { activity before } 1936\end{array}$ & $\begin{array}{l}\text { Activity during } \\
\text { the Civil War }\end{array}$ & $\begin{array}{l}\text { Political } \\
\text { party/Trade union } \\
\text { during C.War }\end{array}$ & $\begin{array}{l}\text { Joined Banda } \\
\text { Madrid }\end{array}$ & $\begin{array}{l}\text { Professional activity } \\
\text { in Mexico }\end{array}$ \\
\hline Jesús Aguilar Ruiz & Trombone & $\begin{array}{l}\text { Orchestral musician, } \\
\text { trade union leader at } \\
\text { P.O.M. }\end{array}$ & $\begin{array}{l}\text { Political } \\
\text { commissar, }^{76} \\
\text { trade union leader } \\
\text { at UGT }\end{array}$ & $\begin{array}{l}\text { Party unknown, } \\
\text { UGT }\end{array}$ & $\begin{array}{l}\text { Probably in Mexico } \\
\text { (he was not interned } \\
\text { in the Barcarès } \\
\text { camp) }\end{array}$ & $\begin{array}{l}\text { Orquesta Sinfónica } \\
\text { de la Universidad } \\
\text { (from early } 1940 \text { s) }\end{array}$ \\
\hline $\begin{array}{l}\text { Basilio Aranda Oquillas } \\
\text { (?) }\end{array}$ & $?$ & $?$ & $\begin{array}{l}\text { Musician, Quinto } \\
\text { Cuerpo }\end{array}$ & Communist, UGT & In Barcarès (?) $)^{77}$ & \\
\hline $\begin{array}{l}\text { Juan Arteta Amigo de } \\
\text { Ibero }\end{array}$ & Trumpet & $\begin{array}{l}\text { Student at the } \\
\text { Conservatoire of } \\
\text { Madrid }\end{array}$ & $\begin{array}{l}\text { Musician, Quinto } \\
\text { Cuerpo }\end{array}$ & Communist, UGT & In Barcarès & $\begin{array}{l}\text { Career as popular } \\
\text { musician in Mexico } \\
\text { and Venezuela }\end{array}$ \\
\hline
\end{tabular}

${ }^{76}$ Political commissars were members of the Republican militia who were in charge of the political education of the volunteers.

${ }^{77}$ Aranda Oquillas appears on the passenger list of Sinaia as being a member of the band of the Quinto Cuerpo and having been a resident of the barrack no. 23 at Barcarès. Most musicians of the Banda were indeed residents of this barrack. This makes it likely that he was a member of the Banda Madrid at some point; however, I have not been able to find his name in connection with any documentation about the Banda Madrid in exile. 


\begin{tabular}{|c|c|c|c|c|c|c|}
\hline $\begin{array}{l}\text { Manuel Casay Sánchez } \\
\text { (in some sources: } \\
\text { Manuel Casay } \\
\text { Colmenero) }\end{array}$ & Percussion & $?$ & $\begin{array}{l}\text { Musician, Quinto } \\
\text { Cuerpo }\end{array}$ & Communist, UGT & In Barcarès & $\begin{array}{l}\text { Orquesta Nacional de } \\
\text { México, percussion } \\
\text { teacher }\end{array}$ \\
\hline Narcís Costa i Horts & Clarinet & $\begin{array}{l}\text { Composer of cobla } \\
\text { and sardana, } \\
\text { clarinettist at the } \\
\text { Orquestra de Girona } \\
\text { and others }\end{array}$ & $\begin{array}{l}\text { Music pedagogy } \\
\text { teacher for the } \\
\text { Catalan } \\
\text { government }\end{array}$ & $\begin{array}{l}\text { Izquierda } \\
\text { Republicana, UGT }\end{array}$ & In Barcarès & $\begin{array}{l}\text { Conductor of the } \\
\text { Orfeó Catalá de } \\
\text { Méxic, teacher }\end{array}$ \\
\hline Agustín Díaz Gómez & $?$ & $?$ & $\begin{array}{l}\text { Musician, Quinto } \\
\text { Cuerpo }\end{array}$ & Communist, UGT & In Barcarès & $?$ \\
\hline $\begin{array}{l}\text { Pablo Espinaco del } \\
\text { Amo (?) }\end{array}$ & $?$ & $?$ & $\begin{array}{l}\text { Musician, Quinto } \\
\text { Cuerpo }\end{array}$ & Communist, UGT & In Barcarès $(?)^{78}$ & $?$ \\
\hline $\begin{array}{l}\text { Tomás Fernández } \\
\text { Rodríguez }\end{array}$ & Trumpet & Orchestral musician & $\begin{array}{l}\text { Musician, Quinto } \\
\text { Cuerpo }\end{array}$ & None, UGT & In Barcarès & $\begin{array}{l}\text { Orquesta Nacional } \\
\text { and Orquesta de } \\
\text { Cámara de México, } \\
\text { teacher }\end{array}$ \\
\hline $\begin{array}{l}\text { Pedro García } \\
\text { Mendizábal }\end{array}$ & $\begin{array}{l}\text { Flute, piccolo, } \\
\text { conductor }\end{array}$ & $\begin{array}{l}\text { Banda Municipal de } \\
\text { Madrid }\end{array}$ & $\begin{array}{l}\text { Piccolo at the } \\
\text { Orquesta de } \\
\text { Conciertos }\end{array}$ & $?$ & Probably in Mexico & $\begin{array}{l}\text { Soloist in radio, TV } \\
\text { and cinema } \\
\text { ensembles }\end{array}$ \\
\hline Adolfo Luque & $?$ & Military musician & $\begin{array}{l}\text { Musician, Quinto } \\
\text { Cuerpo }\end{array}$ & Communist, UGT & In Barcarès & $?$ \\
\hline $\begin{array}{l}\text { Juan Manzanera } \\
\text { Fernández }\end{array}$ & $?$ & Military musician & $\begin{array}{l}\text { Musician, Quinto } \\
\text { Cuerpo }\end{array}$ & $\begin{array}{l}\text { Communist, no } \\
\text { trade union }\end{array}$ & In Barcarès & $?$ \\
\hline $\begin{array}{l}\text { Ernesto Marquina } \\
\text { Labarta }\end{array}$ & Oboe & $?$ & $\begin{array}{l}\text { Musician, Quinto } \\
\text { Cuerpo }\end{array}$ & Communist, UGT & In Barcarès & $\begin{array}{l}\text { Orquesta de la Ópera, } \\
\text { Orquesta Nacional }\end{array}$ \\
\hline $\operatorname{Miranda}^{79}(?)$ & French horn & $?$ & $?$ & $?$ & $?$ & $\begin{array}{l}\text { Radio and TV } \\
\text { orchestras }\end{array}$ \\
\hline $\begin{array}{l}\text { Mariano del Olmo } \\
\text { Crespo }\end{array}$ & $?$ & $\begin{array}{l}\text { Military musician at } \\
\text { the King's regiment }\end{array}$ & $\begin{array}{l}\text { Musician, Quinto } \\
\text { Cuerpo }\end{array}$ & Communist, UGT & In Barcarès & $?$ \\
\hline
\end{tabular}

${ }^{78}$ Same as Aranda Oquillas, above.

${ }^{79}$ Named by Simón Tapia Colman, with no indication of first name. No individual with Miranda as their first or second surnames was found on the list of passengers of the Sinaia, or in connection with Banda Madrid in Mexico. 


\begin{tabular}{|c|c|c|c|c|c|c|}
\hline Rafael Oropesa Clausín & Conductor & $\begin{array}{l}\text { Band leader, } \\
\text { composer of popular } \\
\text { music }\end{array}$ & $\begin{array}{l}\text { Conductor, } \\
\text { Quinto Cuerpo }\end{array}$ & Communist, UGT & In Barcarès & \\
\hline Joaquín Palencia & Bassoon & $\begin{array}{l}\text { Orquesta } \\
\text { Filarmónica, military } \\
\text { musician }\end{array}$ & $\begin{array}{l}\text { Musician, Quinto } \\
\text { Cuerpo }\end{array}$ & Communist, UGT & In Barcarès & $\begin{array}{l}\text { Orquesta de Cámara } \\
\text { de la Escuela } \\
\text { Nacional } \\
\text { Preparatoria, } \\
\text { Orquesta Nacional, } \\
\text { bassoon teacher }\end{array}$ \\
\hline Fernando Ríos Pérez & $?$ & $?$ & $\begin{array}{l}\text { Musician, Quinto } \\
\text { Cuerpo }\end{array}$ & Communist, UGT & In Barcarès & $\begin{array}{l}\text { Worked in Vulcano } \\
\text { (metal industry) }\end{array}$ \\
\hline $\begin{array}{l}\text { Antonio Rivas } \\
\text { Fernández }\end{array}$ & $?$ & $?$ & $\begin{array}{l}\text { Musician, Quinto } \\
\text { Cuerpo }\end{array}$ & Communist, UGT & In Barcarès & $?$ \\
\hline Pedro Sacristán Simón & $?$ & $?$ & $\begin{array}{l}\text { Musician, Quinto } \\
\text { Cuerpo }\end{array}$ & Communist, UGT & In Barcarès & $?$ \\
\hline $\begin{array}{l}\text { Martín San José } \\
\text { Taravillo }\end{array}$ & French horn & $\begin{array}{l}\text { Banda Municipal de } \\
\text { San Sebastián, } \\
\text { member of P.O.M. } \\
\text { (possibly orchestral } \\
\text { musician also in } \\
\text { Madrid?) }\end{array}$ & $\begin{array}{l}\text { Musician, Quinto } \\
\text { Cuerpo }\end{array}$ & Communist, UGT & In Barcarès & $\begin{array}{l}\text { Orquesta Nacional de } \\
\text { México, choral } \\
\text { conductor (Orfeón } \\
\text { Manuel Falla, Coro } \\
\text { de Mujeres } \\
\text { Antifascistas) }\end{array}$ \\
\hline Luis Santos Martín & Cello & $\begin{array}{l}\text { Member of the } \\
\text { Teatro Apolo } \\
\text { orchestra and the } \\
\text { Orquesta } \\
\text { Filarmónica de } \\
\text { Madrid, member of } \\
\text { the AMIS string } \\
\text { quartet, trade unión } \\
\text { leader at P.O.M. }\end{array}$ & $\begin{array}{l}\text { Member of the } \\
\text { Orquesta de } \\
\text { Conciertos, trade } \\
\text { union leader, } \\
\text { political } \\
\text { commissar }\end{array}$ & PSOE, UGT & In Barcarès & $\begin{array}{l}\text { Radio and TV } \\
\text { orchestras }\end{array}$ \\
\hline Juan Santos Ojeda & $?$ & $\begin{array}{l}\text { Composer of } \\
\text { pasodobles }\end{array}$ & $\begin{array}{l}\text { Musician, Quinto } \\
\text { Cuerpo }\end{array}$ & Communist, UGT & In Barcarès & $?$ \\
\hline $\begin{array}{l}\text { Enrique Suárez } \\
\text { Sandoval }\end{array}$ & $?$ & $?$ & $\begin{array}{l}\text { Musician, Quinto } \\
\text { Cuerpo }\end{array}$ & Communist, UGT & In Barcarès & $?$ \\
\hline
\end{tabular}




\begin{tabular}{|c|c|c|c|c|c|c|}
\hline Timoteo Traba Ricote & Bassoon & \begin{tabular}{|ll}
$?$ \\
\end{tabular} & $\begin{array}{l}\text { Musician, Quinto } \\
\text { Cuerpo }\end{array}$ & Communist, UGT & In Barcarès & $\begin{array}{l}\text { Orquesta Nacional de } \\
\text { México, Orquesta del } \\
\text { Teatro Bellas Artes, } \\
\text { Quinteto Nacional } \\
\text { UNAM, bassoon } \\
\text { teacher }\end{array}$ \\
\hline
\end{tabular}




\section{References}

Anonymous, 1931a. 'La Junta Nacional de Música y Teatros Líricos. Protesta de la Sociedad de Autores', in El Heraldo de Madrid, 27 June 1931: 5.

Anonymous, 1931b. 'La Junta Nacional de Música y Teatros Líricos', in Ritmo 35: 3.

Anonymous, 1931c. 'Conferencia nacional sobre la crisis musical', in Ritmo 36: 3-4.

Anonymous, 1931d. 'Plebiscito Nacional de Profesores de Orquesta', in Ritmo 42: 10-11

Anonymous, 1932. 'El primer congreso de la Federación Española de Espectáculos inaugura sus trabajos', in Ahora, 12 July 1932: 31.

Anonymous, 1933. 'Los actores parados', in La libertad, 20 August 1933: 3.

Anonymous, 1935. 'Compañeros, ¡salud!', in P.O.M. 1: 1-3.

Anonymous, 1936a. 'Ópera en Madrid o en el Calderón nos encontraremos', in P.O.M. 5: 3.

Anonymous, 1936b. 'La Asociación de Profesores de Orquesta', in La libertad, 26 July 1936: 12.

Anonymous, 1936c. 'Conciertos', in La libertad, 13 September 1936: 12.

Anonymous, 1936d. 'La Asociación de Profesores de Orquesta', in Ahora, 1 August 1936: 8.

Anonymous, 1940. 'Un homenaje de los republicanos españoles al General Cárdenas', in España popular, 7 December 1940: 6.

Anonymous, 1942a. 'Centenares de mexicanos y españoles de la vieja y nueva emigración asistieron al baile a beneficio de la 'Banda Madrid', in España popular, 29 August 1942: 4.

Anonymous, 1942b. 'La guardia al cadáver y el entierro de Pedro Checa constituyeron una emocionante y viva expresión de condolencia', in España popular, 12 August 1942: 2.

Anonymous, 1942c. 'La velada en homenaje a Jesús Larrañaga', in España popular, 11 September 1942: 3. 
Anonymous, 1942d. 'La última lista pro-ambulancia', in España popular, 3 January 1942: 3.

Anonymous, 1943a. 'Actuación de la Banda Madrid y del Coro Vasco', in España popular, 2 April 1943: 3.

Anonymous, 1943b. 'El gran festival de Bellas Artes', in España popular, 7 May 1943: 3.

Anonymous, 1944a. 'Adhesiones en México a la Junta Suprema', in España popular, 7 April 1944: 5.

Anonymous, 1944b. 'Los comunistas españoles en México recaudan 15.000 pesos para sus camaradas en España', in España popular, 14 July 1944: 3.

Anonymous, 1946a. 'Final del pleno', in España popular, 7 June 1946: 4.

Anonymous, 1946b. 'Fondo Cristino García', in España popular, 26 April 1946: 5.

Anonymous, 1946c. 'Vida de partido', in España popular, 23 August 1946: 6.

Anonymous, 1947. 'Información final sobre el V Pleno en México', in España popular, 16 May: 2.

Abellán, José Luis, 1976. El exilio español de 1939 (Madrid: Taurus).

Abellán, José Luis, 1983. De la guerra civil al exilio republicano (1936-1977) (Madrid: Mezquita).

Alted, Alicia, 2005. La voz de los vencidos. El exilio republicano de 1939 (Madrid: Aguilar).

Aronson, Josh and George, Denise, 2016. Orchestra of exiles (New York: Berkley).

Bacarisse, Salvador, 1936. 'Conciertos', in P.O.M. 3: 5-6.

Bal y Gay, Jesús and García Ascot, Rosa, 1990. Nuestros trabajos y nuestros días (Madrid: Banco Pastor).

Balibrea, Mari Paz, 2005. 'Rethinking Spanish Republican Exile. An introduction', in Journal of Spanish Cultural Studies 6: 3-24. 
Balibrea, Mari Paz, 2010. 'De los Cultural Studies a los estudios culturales: el caso del exilio republicano', in Journal of Spanish Cultural Studies, 11: 251-262.

Baroni, [no first name given], 1935. ‘¿A qué esperamos?, in P.O.M. 4: 10.

Brinkmann, Reinhold and Wolff, Christoff (eds.), 1999. Driven into Paradise. The Musical Migration from Nazi Germany to the United States (Berkeley, Los Angeles and London: University of California Press).

Brugués i Agustí, Lluís and Vidal i Comellas, Elisenda, 2011. 'El llarg exili de Narcís Costa-Horts', in Revista de Girona 266: 50-2.

Carrión Sánchez, Pablo Jesús, 2004. 'La delegación del PCE en México (1939-1956). Origen y límite de una voluntad de liderazgo de la oposición', in Espacio, tiempo y forma 16: 309-336.

Casares Rodicio, Emilio, 1987. 'La música española hasta 1939, o la restauración musical', in Emilio Casares Rodicio, Ismael Fernández de la Cuesta and José López-Calo (eds.), 1987. España en la música de Occidente (Madrid: INAEM), 261-322.

Caudet, Francisco, 2005. El exilio republicano de 1939 (Madrid: Cátedra).

De Hoyos Puente, Jorge, 2012a. 'La formación de la identidad del refugiado: los republicanos españoles en México, discursos, prácticas y horizontes de futuro', in Laberintos. Revista de estudios sobre los exilios culturales españoles 14: 49-68.

De Hoyos Puente, Jorge, 2012b. 'Discrepancias entre patriotas: ideas de estado en los imaginarios políticos del exilio republicano en México, 1939-1950', in Migraciones y Exilios 13: 11-32.

De Hoyos Puente, Jorge, 2014. 'México y las instituciones republicanas en el exilio: del apoyo del Cardenismo a la instrumentación política del Partido Revolucionario Institucional, 1939-1977’, in Revista de Indias 260: 275-306

De Hoyos Puente, Jorge, 2016. 'La evolución del negrinismo en el exilio republicano en México', in Historia y politica 36: 313-337. 
F.P., 1935. 'Orientaciones', in P.O.M. 2: 5-6

F.P., 1936. 'Orientaciones', in P.O.M. 4: 5-6.

Faber, Sebastiaan, 2005. 'Silencios y tabúes del exilio español en México', in Espacio, Tiempo y Forma. Serie V. Historia Contemporánea 17: 373-389.

Faber, Sebastiaan and Martínez-Carazo, Cristina, 2010. 'Problemas y paradojas del exilio español en Estados Unidos', in in Sebastiaan Faber and Cristina Martínez-Carazo (eds.), 2010. Contra el olvido. El exilio español en Estados Unidos. (Alcalá de Henares: Instituto Franklin de Estudios Norteamericanos), 9-26.

Fagen, Patricia W., 1973. Exiles and Citizens. Spanish Republicans in Mexico (Austin and London: University of Texas Press)

Fernández Granell, Eugenio, 1991. ‘Exilio partido en dos’, in José María Naharro Calderón (ed.), 1991. El exilio de las Españas de 1939 en las Américas: ‘¿Adónde fue la canción?’. (Barcelona: Anthropos), 133-143.

Flores, Xavier, 2001. 'El Gobierno de la República en el exilio. Crónica de un imposible retorno', in Espacio, Tiempo y Forma 14: 309-350.

Juliá, Santos, 1982. 'La UGT de Madrid en los años treinta: Un sindicalismo de gestión', in Reis: Revista Española de Investigaciones Sociológicas 20: 121-151.

López, Helena, 2004. 'Exilio, memoria e industrias culturales: esbozo para un debate', in Migraciones $y$ Exilios 5: 25-36.

Martínez, Carlos, 1959. Crónica de una emigración. La de los republicanos españoles en 1939 (Mexico City, Libro Mex).

Mateos, Abdón, 2002. 'Los republicanos españoles en el México cardenista', in Ayer 47: 103-128. 
Matesanz, José Antonio, 1999. Las raíces del exilio: México ante la Guerra Civil Española (Mexico City: El Colegio de México/Universidad Autónoma de México).

Mora, Pablo and Miguel, Ángel, 2006. Barco en tierra: España en México (Madrid: Fundación Pablo Iglesias/Universidad Autónoma de México).

Moreda Rodríguez, Eva, 2015. Music and exile in Francoist Spain (Farnham: Ashgate, 2015).

Pareyón, Gabriel, 1995. Diccionario de Música en México, vol. 1 (Guadalajara: Secretaría de Cultura de Jalisco/CONACULTA).

Pérez Guerrero, Juan Carlos, 2002. 'Espacios, dinámicas y discursos en el exilio republicano en México', in Studia Zamorensia 6: 317-335.

Pla Brugat, Dolores, 2003. El aroma del recuerdo: narraciones de espanoles republicanos refugiados en México (Ciudad de México: Conaculta, 2003).

Redero San Román, Manuel, 1983. 'La problemática de la organización de la UGT en la II República', in Studia historica 1: 67-87.

Roces, Wenceslao, 1946. ‘¡Hacia los 500.000 pesos!’, in España popular, 14 June 1946: 5.

Romero Samper, Milagrosa, 2005. La oposición durante el franquismo/3. El exilio republicano (Madrid: Encuentro).

Rozado, Jesús, 1946. 'Algunos resultados logrados en el estudio y la educación política en el Partido', in España popular, 16 August 1946: 5.

Ruiz de la Serna, E., 1934. 'La Junta Nacional de Música, la próxima temporada de ópera rusa y el hambre de los artistas españoles', in El Heraldo de Madrid, 20 February 1934: 4.

Ruiz-Funes Montesinos, Concepción and Tunón, Enriqueta, 1982. Palabras del exilio 2. Final y comienzo: el Sinaia (Mexico City: Instituto Nacional de Antropología e Historia). 
Soo, Scott, 2013. The routes to exile: France and the Spanish Civil War refugees, 1939-2009 (Manchester: Manchester University Press).

Tapia Colman, Simón, 1991. Música y músicos de México (Mexico City: Panorama). 